\title{
ORNAMENTAL PEPPER ON REFLECTIVE BENCH UNDER PROTECTED ENVIRONMENTS
}

\author{
Edilson Costa ${ }^{1 *}$, Ranna S. R. Reche ${ }^{1}$, Abimael G. da Silva ${ }^{2}$, \\ Flávio F. da S. Binotti ${ }^{1}$, Murilo B. Martins ${ }^{1}$, Tiago Zoz ${ }^{1}$
}

\author{
${ }^{1 *}$ Corresponding author. Universidade Estadual de Mato Grosso do Sul/ Cassilândia - MS, Brasil. \\ Email: edilson.costa@uems.br | ORCID ID: http://orcid.org/0000-0002-4584-6611
}

\author{
KEYWORDS \\ Plant ambiance, \\ aluminized screen, \\ Pyramid cultivar, \\ Capsicum frutescens.
}

\begin{abstract}
Plant ambiance studies the environmental condition favorable to plant growth at the initial stage of seedlings or the complete production cycle. This study aimed to evaluate the cultivation of the ornamental pepper 'Pyramid' under protected environments and growing benches with and without reflective material. The protected environments consisted of a greenhouse covered with low-density polyethylene film and 42/50\% shading thermo-reflective screen under the film, structure with $35 \%$ shading thermoreflective aluminized screen, and structure with $30 \%$ shading black screen. The growing benches were tested in environments without and with reflective material made of aluminized screen. The environment of the agricultural greenhouse covered with lowdensity polyethylene film and $42 / 50 \%$ thermo-reflective screen under the film favored the growth of ornamental pepper plants regarding height and diameter and provided early flowering and high fruit production. The use of the reflective material showed no significant results for plant height, stem diameter, and the number of leaves. The use of reflective material increased the number of fruits in plants under the environments with $35 \%$ shading aluminized screen and $30 \%$ shading black screen.
\end{abstract}

\section{INTRODUCTION}

Ornamental pepper (Capsicum spp.), belonging to the family Solanaceae and originating in tropical regions, is marketed as an annual potted plant, being appreciated for the color of its fruits, which is its main characteristic. It has a high acceptance in the consumer market, but its production is little studied. The ornamental pepper of the cultivar Pyramid, with a unique beauty due to its colorful fruits, has better seedling development in the Cassilândia region than the cultivar Etna (Costa et al., 2015).

Ornamental pepper production is carried out in protected environments since it is marketed in pots. Studies on plant growth and production of pepper cultivars in pots (Tupã Bode Vermelha, Boyra Habanero Vermelha, Etna, and Pyramid) under different protected environments have found that the greenhouse was the most suitable for all cultivars, followed by the structure with $50 \%$ shading black screen for the cultivars Tupã and Boyra and the structure with $50 \%$ shading aluminized screen for the cultivar Pyramid (Costa et al., 2017). Studies conducted with the cultivar Pyramid in agricultural greenhouses and different pot colors showed that the greenhouse with the highest shade under the film promoted better initial growth and precocity in fruit production (Costa et al., 2020a).

Cultivation under protected environments allows horticulturists to produce all year round depending on the species and region. There are different types of protected environments and different structures. The main coverings used in these environments are shading screens or lowdensity polyethylene (LDPE) film. Screens present different colors, mostly black and aluminized silver (thermoreflective), and the 150-micron low-density polyethylene film is the most used both alone and associated with screens (Costa et al., 2010). These covering materials are intended to reduce damage to the plant tissue in the initial stages, providing better conditions for the seedling formation and crop production.

\footnotetext{
${ }^{1}$ Universidade Estadual de Mato Grosso do Sul/ Cassilândia - MS, Brasil.

${ }^{2}$ Universidade Estadual Paulista/ Ilha Solteira - SP, Brasil.
}

Area Editor: Héliton Pandorfi

Received in: $12-23-2020$

Accepted in: 3-1-2021 
According to Salles et al. (2017), studies have been conducted to compare different protected environments and shading levels in the search to identify the favorable environmental condition for the initial plant growth, being currently aimed at the association of protected environments and benches with reflective material. These authors reported that the use of growing benches covered with reflective material, another component of the plant ambiance, aims to intercept part of the photosynthetically active radiation (PAR) and redirect it to the leaves that are normally shaded. PAR is responsible for influencing plant growth and phenology and its intensity can modify the structure of leaves, chloroplasts, and pigments (Taiz et al., 2017).

The use of reflective material on growing benches has positively influenced the formation of seedlings of yellow passion fruit (Passiflora edulis Sims f. flavicarpa Deg.) (Santos et al., 2017), Java plum (Syzygium cumini) (Salles et al., 2017 ), paricá (Schizolobium amazonicum) (Mortate et al., 2019), baru (Dipteryx alata) (Costa et al., 2020b, c), and papaya (Carica papaya) (Cabral et al., 2020).

Thus, this study aimed to evaluate the production of ornamental pepper of the cultivar Pyramid under different cultivation environments and reflective material on the growing bench.

\section{MATERIAL AND METHODS}

The experiments were conducted from February to June 2017 at the State University of Mato Grosso do Sul, campus of Cassilândia, MS, Brazil, at the geographic coordinates $19^{\circ} 07^{\prime} 21^{\prime \prime} \mathrm{S}$ and $51^{\circ} 43^{\prime} 15^{\prime \prime}$, with an altitude of $516 \mathrm{~m}$.

Three protected environments were used: a) $18.0 \times 8.0 \times 3.5-\mathrm{m}$ galvanized steel agricultural structure, with a $30 \%$ shading black monofilament screen closed at 45 degrees (black screen); b) $18.0 \times 8.0 \times 3.5$-m galvanized steel structure, with a $35 \%$ shading thermo-reflective aluminized screen closed at 45 degrees (aluminized screen); and c) $18.0 \times 18.0 \times 4.0-\mathrm{m}$ galvanized steel agricultural greenhouse, with a 150-micron low-density polyethylene (LDPE) film (light diffuser and anti-drip), zenith opening sealed with a $30 \%$ white screen, $30 \%$ shading black side and front screen, closed at $90^{\circ}$, and $42 / 50 \%$ shading movable LuxiNet $^{\circledR}$ aluminized thermo-reflective screen under the film (plastic greenhouse). Growing benches with (WRM) and without (NRM) reflective material were tested inside the protected environments using an aluminized thermo-reflective screen (Aluminet $^{\circledR}$ ).

Each environment was considered an experiment because there were no replications of the protected environments. The experimental design used in each environment was completely randomized with four replications and seven plants per plot. Initially, the data were subjected to analysis of variance of the individual benches, followed by the evaluation of the mean squared residuals and the joint analysis of the experiments (Banzatto \& Kronka, 2013) in a $3 \times 2$ factorial (3 protected environments and 2 types of benches, that is, with and without reflective material). The statistical software Sisvar 5.3 (Ferreira, 2010) was used, with the means subjected to the F-test and compared by the Tukey test (environments) and F-test (growing benches), both at $5 \%$ probability.

The pepper seeds were acquired commercially and sown in 72-cell expanded polystyrene trays (Rodrigues et al., 2010; Oliveira et al., 2012). Seedlings with four to five definitive leaves were transplanted to the $1.5-\mathrm{L}$ pots filled with a substrate composed of $20 \%$ bovine manure, $50 \%$ soil (Quartzipsamment), and 30\% vermiculite.

The cultivation substrate presented the following chemical characteristics: $\mathrm{pH}$ in $\mathrm{CaCl}_{2}$ of 5.6, organic matter $(\mathrm{OM})$ of $26.6 \mathrm{~g} \mathrm{dm}^{-3}, \mathrm{P}_{\text {Mehlich-1 }}$ of $75.3 \mathrm{mg} \mathrm{dm}^{-3}, \mathrm{~K}^{+}$of 0.54 $\mathrm{cmol}_{\mathrm{c}} \mathrm{dm}^{-3}, \mathrm{Ca}^{2+}$ of $2.20 \mathrm{cmol}_{\mathrm{c}} \mathrm{dm}^{-3}, \mathrm{Mg}^{2+}$ of $2.00 \mathrm{cmol}_{\mathrm{c}}$ $\mathrm{dm}^{-3}, \mathrm{Al}^{3+}$ of $0.05 \mathrm{cmol}_{\mathrm{c}} \mathrm{dm}^{-3}, \mathrm{H}+\mathrm{Al}$ of $2.00 \mathrm{cmol}_{\mathrm{c}} \mathrm{dm}^{-3}$, cation exchange capacity (CEC) of $6.7 \mathrm{cmol}_{\mathrm{c}} \mathrm{dm}^{-3}$, base saturation of $70.3 \%$, B of $0.66 \mathrm{mg} \mathrm{dm}^{-3}, \mathrm{Cu}$ of $0.8 \mathrm{mg} \mathrm{dm}^{-3}$, Fe of $104 \mathrm{mg} \mathrm{dm}^{-3}$, Mn of $37.8 \mathrm{mg} \mathrm{dm}^{-3}$, and $\mathrm{Zn}$ of $6.4 \mathrm{mg}$ $\mathrm{dm}^{-3}$. The pots were fertilized with $1.0 \mathrm{~g}$ of 4-18-08 (NPK) at 20 days after transplanting (DAT). Nitrogen (urea) was applied at $40 \mathrm{DAT}$ at a dose of $30 \mathrm{~kg} \mathrm{~N} \mathrm{ha}^{-1}$.

Plant height, stem diameter, number of leaves, and number of fruits were evaluated at $30,45,60,75$, and 90 DAT. Plant height was measured using a ruler, considering the distance from the plant base to its apical meristem. The stem diameter was obtained using a digital caliper ( $\mathrm{mm}$ ). Leaves and fruits were quantified by a non-destructive method. The canopy projection area was measured at 90 DAT, considering the average of the diameters in two perpendicular directions. The first flowers were observed at 15 DAT in the agricultural greenhouse.

The photosynthetically active radiations (PAR) $\left(\mu \mathrm{mol} \mathrm{m} \mathrm{m}^{-2} \mathrm{~s}^{-1}\right.$ ) incident on the cultivation and external environments, as well as the PAR reflected on the growing benches, were monitored using an Apogee MQ-200 Quantum separate sensor with handheld meter at the radiation range from 400 to $700 \mathrm{~nm}$ on clear days (without cloudiness) at 9:30 am from March 14 to June 28, 2017. The incident (simple scheme) and reflected (factorial scheme) PAR data were compared in a randomized block design with four replications (March, April, May, and June).

\section{RESULTS AND DISCUSSION}

The photosynthetically active radiation (PAR) incident on the cultivation environments decreased as a function of the type of environment and constituent materials. The lowest PAR was found in the greenhouse covered with low-density polyethylene film and a $42 / 50 \%$ shading screen under the film, followed by the $35 \%$ shading aluminized screen, both showing PAR values lower than that of the $30 \%$ shading screen (Figure 1). 


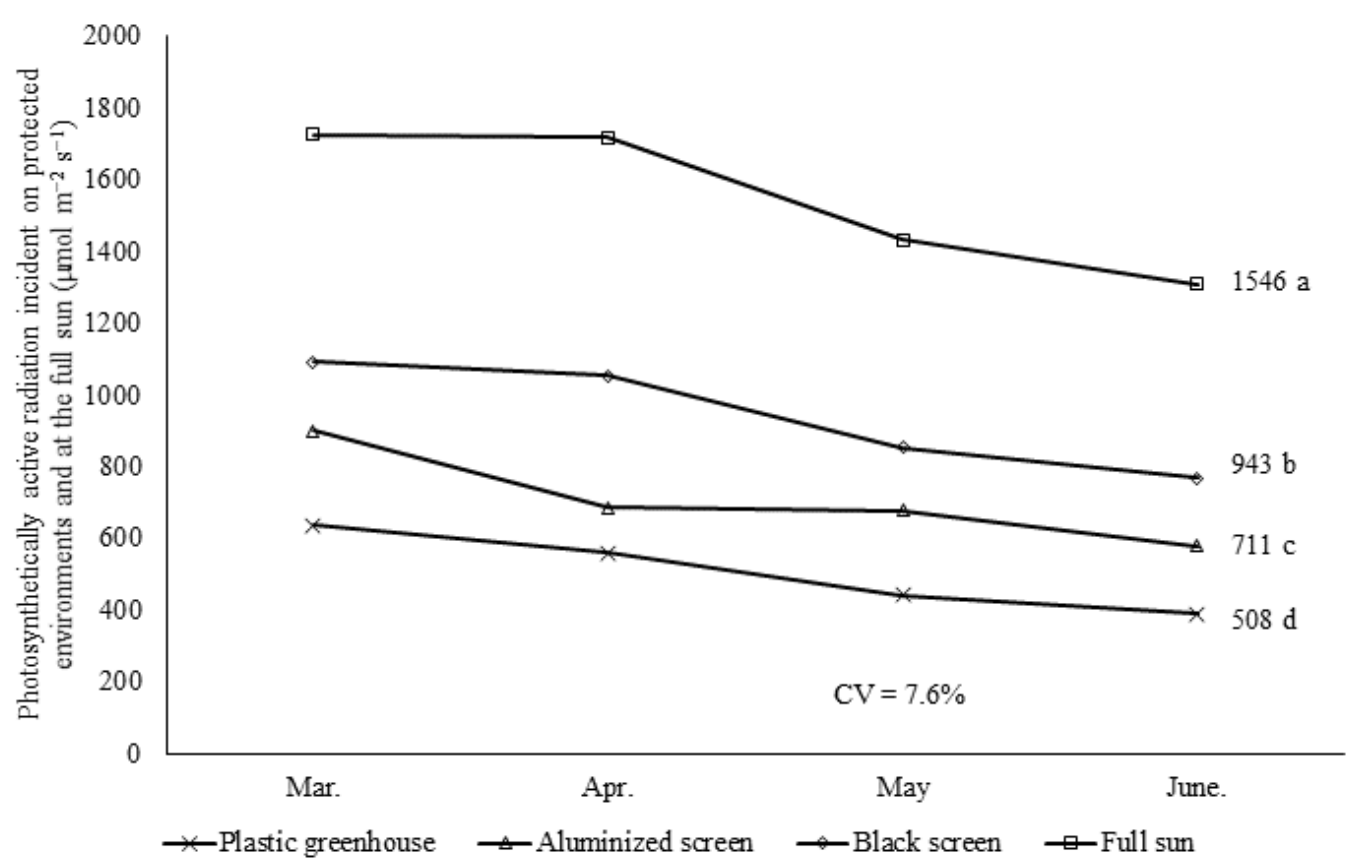

FIGURE 1. Photosynthetically active radiation (PAR) incident on protected environments and at the full sun. Means followed by the same lowercase letter do not differ from each other by the Tukey test at a 5\% probability. CV = coefficient of variation.

The incident PAR at full sun consisted of $1546 \mu \mathrm{mol}$ $\mathrm{m}^{-2} \mathrm{~s}^{-1}$, with, on average, $33 \%$ reaching the inside of the greenhouse, $46 \%$ the aluminized screen, and $61 \%$ the black screen during the studied period (Figure 1). These results show that the shading value does not correspond to the percentage of PAR inside the environment, as the $30 \%$ shading black screen and $35 \%$ aluminized screen allowed only 61 and $46 \%$ of the external PAR to pass, respectively.
The reflected PAR was higher inside the black screen than in the agricultural greenhouse and represented the means of the control benches and growing benches with reflective material. The growing bench with reflective material provided higher reflected PAR than in the control bench, being $96 \%$ higher, on average, considering the three environments (Figure 2).

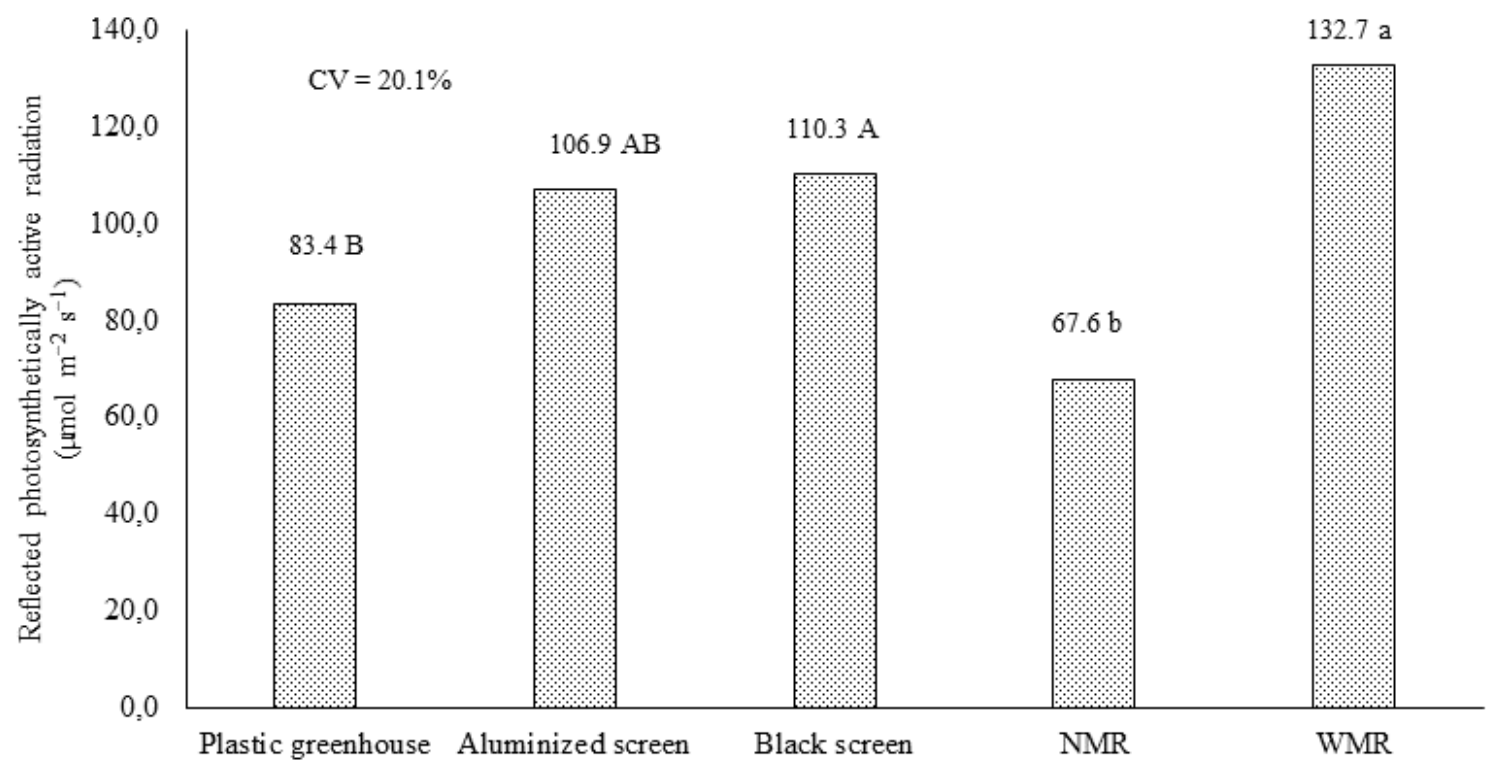

FIGURE 2. Photosynthetically active radiation (PAR) reflected on growing benches with (WRM) and without (NRM) reflective material inside the protected environments. Means followed by the same lowercase letter for benches (F-test) and uppercase letter for protected environments (Tukey test) do not differ from each other at a $5 \%$ probability. $\mathrm{CV}=$ coefficient of variation.

The variables plant height $(\mathrm{PH})$ at $30,45,60,75$, and 90 days after transplanting (DAT), stem diameter (SD) at $30,45,60,75$, and 90 DAT, number of leaves (NL) at 45, 60 , and 75 DAT, and canopy area (CA) allowed performing the joint analysis and comparison of the types of environments, as the ratio between the highest and lowest mean squared residuals (RMSR) was lower than 7 (Table 1). The variables number of leaves (NL) at 30 and 90 DAT and number of fruits (NF) at 30, 45, 60, 75, and 90 DAT had an RMSR value higher than 7 , not allowing the joint analysis (Table 1) and comparison of environments to be performed (Banzato \& Kronka, 2013). 
TABLE 1. Mean squared residuals and ratio between the highest the lowest mean squared residuals (RMSR) for plant height (PH), stem diameter (SD), number of leaves (NL), number of fruits (NF) at 30, 45, 60, 75, and 90 days after transplanting (DAT), and canopy projection area (CA) of ornamental pepper plants inside each protected environment.

\begin{tabular}{|c|c|c|c|c|c|c|c|}
\hline \multirow{3}{*}{ Environment } & \multicolumn{7}{|c|}{ Mean squared residuals } \\
\hline & PH30 & PH45 & PH60 & PH75 & PH90 & SD30 & SD45 \\
\hline & DAT & DAT & DAT & DAT & DAT & DAT & DAT \\
\hline Plastic greenhouse & 0.153 & 0.554 & 0.073 & 0.066 & 0.031 & 0.028 & 0.007 \\
\hline Aluminized screen & 0.213 & 0.478 & 0.044 & 0.156 & 0.139 & 0.019 & 0.011 \\
\hline Black screen & 0.193 & 0.403 & 0.267 & 0.186 & 0.132 & 0.014 & 0.004 \\
\hline RMSR & 1.39 & 1.37 & 6.01 & 2.80 & 4.47 & 2.08 & 2.50 \\
\hline \multirow{2}{*}{ Environment } & SD60 & SD75 & SD90 & NL30 & NL45 & NL60 & NL75 \\
\hline & DAT & DAT & DAT & DAT & DAT & DAT & DAT \\
\hline Plastic greenhouse & 0.041 & 0.037 & 0.079 & 17.188 & 58.287 & 20.488 & 40.776 \\
\hline Aluminized screen & 0.016 & 0.017 & 0.027 & 113.508 & 28.985 & 7.770 & 23.312 \\
\hline Black screen & 0.022 & 0.023 & 0.017 & 11.199 & 9.426 & 19.085 & 10.024 \\
\hline RMSR & 2.51 & 2.18 & 4.72 & 10.14 & 6.18 & 2.64 & 4.07 \\
\hline \multirow{2}{*}{ Environment } & NL90 & NF30 & NF45 & NF60 & NF75 & NF90 & \multirow{2}{*}{$\mathrm{CA}$} \\
\hline & DAT & DAT & DAT & DAT & DAT & DAT & \\
\hline Plastic greenhouse & 54.839 & 0.195 & 2.466 & 10.869 & 4.736 & 5.439 & 755.223 \\
\hline Aluminized screen & 39.320 & 0.025 & 0.671 & 1.528 & 1.247 & 0.970 & 300.774 \\
\hline Black screen & 6.461 & 0.053 & 0.164 & 0.195 & 0.618 & 0.445 & 158.979 \\
\hline RMSR & 8.49 & 7.80 & 15.00 & 55.82 & 7.66 & 12.24 & 2.51 \\
\hline
\end{tabular}

The slicing between factors in the variables that presented an RMSR lower than 7 showed an interaction between protected environments and growing benches with and without reflective material $(\mathrm{E} \times \mathrm{B})$ only for plant height at 60 DAT. The number of leaves at 60 and 75 DAT showed no significant differences for protected environments, but the other variables presented significance. Stem diameter at 45 DAT and number of leaves at 75 DAT showed significant differences for growing benches with and without reflective material (Table 2).

TABLE 2. Analysis of variance for plant height (PH30, PH45, PH60, PH75, and PH90), stem diameter (SD30, SD45, SD60, SD75, and SD90), number of leaves (NL45, NL60, and NL75), and canopy area of ornamental pepper plants in the slicing between the factors (protected environments $\times$ growing benches with and without reflective material) that presented RMSR values lower than 7 .

\begin{tabular}{|c|c|c|c|c|c|c|c|}
\hline Treatment & $\begin{array}{c}\text { PH30 } \\
\text { DAT }\end{array}$ & $\begin{array}{l}\text { PH45 } \\
\text { DAT }\end{array}$ & $\begin{array}{l}\text { PH60 } \\
\text { DAT }\end{array}$ & $\begin{array}{c}\text { PH75 } \\
\text { DAT }\end{array}$ & $\begin{array}{l}\text { PH90 } \\
\text { DAT }\end{array}$ & $\begin{array}{l}\text { SD30 } \\
\text { DAT }\end{array}$ & $\begin{array}{l}\text { SD45 } \\
\text { DAT }\end{array}$ \\
\hline Environment (E) & $* *$ & $* *$ & $* *$ & $* *$ & $* *$ & $* *$ & $* *$ \\
\hline Bench (B) & ns & ns & ns & ns & ns & ns & $*$ \\
\hline $\mathrm{E} \times \mathrm{B}$ & ns & ns & $*$ & ns & ns & ns & $\mathrm{ns}$ \\
\hline Treatment & $\begin{array}{l}\text { SD60 } \\
\text { DAT }\end{array}$ & $\begin{array}{l}\text { SD75 } \\
\text { DAT }\end{array}$ & $\begin{array}{l}\text { SD90 } \\
\text { DAT }\end{array}$ & $\begin{array}{l}\text { NL45 } \\
\text { DAT }\end{array}$ & $\begin{array}{l}\text { NL60 } \\
\text { DAT }\end{array}$ & $\begin{array}{l}\text { NL75 } \\
\text { DAT }\end{array}$ & $\mathrm{CA}$ \\
\hline Environment (E) & $* *$ & $* *$ & $* *$ & $* *$ & ns & $\mathrm{ns}$ & $* *$ \\
\hline Bench (B) & ns & ns & ns & ns & $\mathrm{ns}$ & $* *$ & ns \\
\hline $\mathrm{E} \times \mathrm{B}$ & $\mathrm{ns}$ & $\mathrm{ns}$ & $\mathrm{ns}$ & ns & ns & $\mathrm{ns}$ & $\mathrm{ns}$ \\
\hline
\end{tabular}

ns $=$ not significant; $*$ significant at $5 \% ; * *$ significant at $1 \%$. DAT $=$ days after transplanting.

The ratios between the highest and lowest mean squared residuals of the number of leaves (NL30 and NL90) and the number of fruits (NF30, NF45, NF60, NF75, and NF90) were higher than 7 and, therefore, an analysis of variance was performed only for growing benches. A significant difference was observed for growing benches with and without reflective material in the aluminized screen for the number of fruits at 90 DAT and the black screen for the number of fruits at 45 and 75 DAT. No significant difference was observed for growing benches with and without reflective material in the agricultural greenhouse (Table 3). 
TABLE 3. Analysis of variance for the number of leaves (NL30 and NL90) and the number of fruits (NF30, NF45, NF60, NF75, and NF90) of ornamental pepper plants in the individual analyses of growing benches with and without reflective material in each protected environment.

\begin{tabular}{lccccccc}
\hline \multicolumn{1}{c}{ Environment } & NL30 & NL90 & NF30 & NF45 & NF60 & NF75 & NF90 \\
& DAT & DAT & DAT & DAT & DAT & DAT & DAT \\
\hline Plastic greenhouse & $\mathrm{ns}$ & $\mathrm{ns}$ & $\mathrm{ns}$ & $\mathrm{ns}$ & $\mathrm{ns}$ & $\mathrm{ns}$ & $\mathrm{ns}$ \\
Aluminized screen & $\mathrm{ns}$ & $\mathrm{ns}$ & $\mathrm{ns}$ & $\mathrm{ns}$ & $\mathrm{ns}$ & $\mathrm{ns}$ & $*$ \\
Black screen & $\mathrm{ns}$ & $\mathrm{ns}$ & $\mathrm{ns}$ & $*$ & $\mathrm{~ns}$ & $*$ & $\mathrm{~ns}$ \\
\hline
\end{tabular}

ns = not significant $; *$ significant at $5 \%$.

A higher plant height was observed in the agricultural greenhouse (42/50\% shading) at 45, 75, and 90 DAT, not differing from the black screen (30\% shading) at 30 DAT (Figure 3). These higher plants in the agricultural greenhouse do not mean possible etiolation in this more shaded environment, with a lower incident PAR (Figure 1) and a lower PAR reflected on the benches (Figure 2), as the highest stem diameters were found in this environment. Costa et al. (2017) found no differences in the height of seedlings of this cultivar in environments of the agricultural greenhouse, 50\% shading aluminized screen, and 50\% shading black screen, but the agricultural greenhouse was the most suitable environment for seedlings and production, followed by Aluminet ${ }^{\circledR}$.

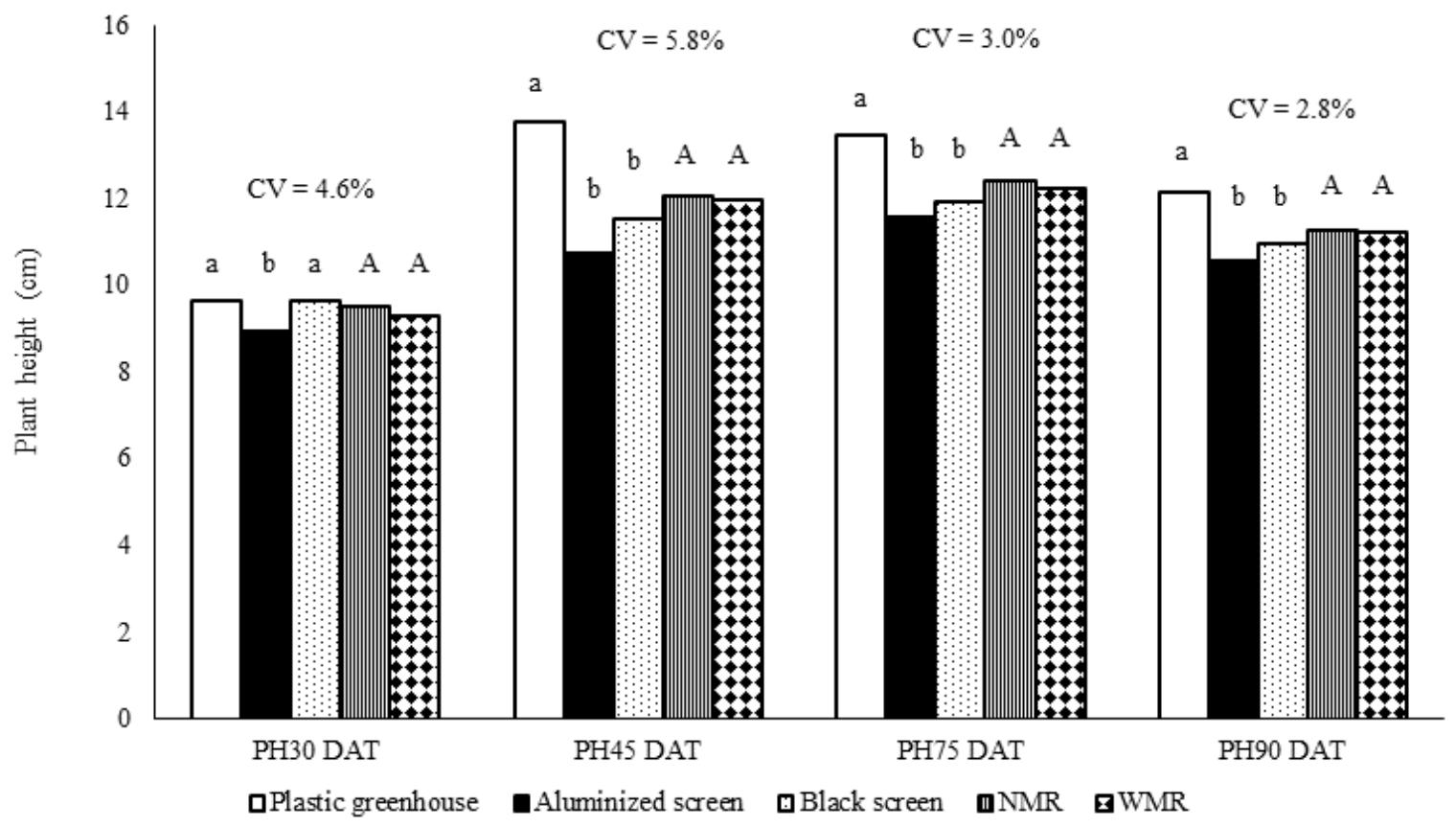

FIGURE 3. Plant height (PH) at 30, 45, 75, and 90 days after transplanting (DAT) in protected environments and on growing benches with (WRM) and without (NRM) reflective material. Means followed by the same lowercase letter for protected environments (Tukey test) and uppercase letters for growing benches with and without reflective material (F-test) do not differ from each other at a $5 \%$ probability. $\mathrm{CV}=$ coefficient of variation.

The highest plant height was found in the agricultural greenhouse at 60 DAT, and the reflective material on the bench did not influence this variable (Table 4), showing the same behavior as in the analysis of the heights of other dates.

TABLE 4. Interaction between environment and reflective material for plant height at 60 days after transplanting ornamental pepper plants in different protected environments and growing benches with and without reflective material.

\begin{tabular}{lcc}
\hline & Plant height at 60 DAT & Without material \\
\hline Environment & With material & $14.27 \mathrm{Aa}$ \\
\hline Plastic greenhouse & $13.83 \mathrm{Aa}$ & $11.08 \mathrm{Ca}$ \\
Aluminized screen & $11.50 \mathrm{Ba}$ & $11.91 \mathrm{Ba}$ \\
Black screen & $11.52 \mathrm{Ba}$ & \\
\hline $\mathrm{CV}(\%)$ & & 2.90 \\
\hline
\end{tabular}

Means followed by the same uppercase letter in the column and lowercase letter in the row do not differ from each other by the Tukey test at $5 \%$ probability for cultivation environments and F-test for growing benches. $\mathrm{CV}=$ coefficient of variation. 
The comparison between environments showed the highest means for the number of leaves in the agricultural greenhouse at 45 DAT, but the environments did not differ from each other at 60 and $75 \mathrm{DAT}$, revealing that the lowest radiation in this environment (Figures 1 and 2) did not influence this variable. The highest number of leaves were found in growing benches with reflective material at 75 DAT (Figure 4). The highest NL at 75 DAT is related to the higher bench reflection (Figure 2), as observed by Santos et al. (2017), Salles et al. (2017), and Mortate et al. (2019).
The highest SD values were observed in seedlings produced in the agricultural greenhouse from 45 to 90 DAT (Figure 5), not corroborating with Costa et al. (2017), who found no differences in the diameter of seedlings of this cultivar in an agricultural greenhouse, 50\% shading aluminized screen, and 50\% shading black screen. However, Binotti et al. (2018) found larger diameters in seedlings produced under 18 and $35 \%$ shading compared to $50 \%$ shading in treatment without a chemical agent.

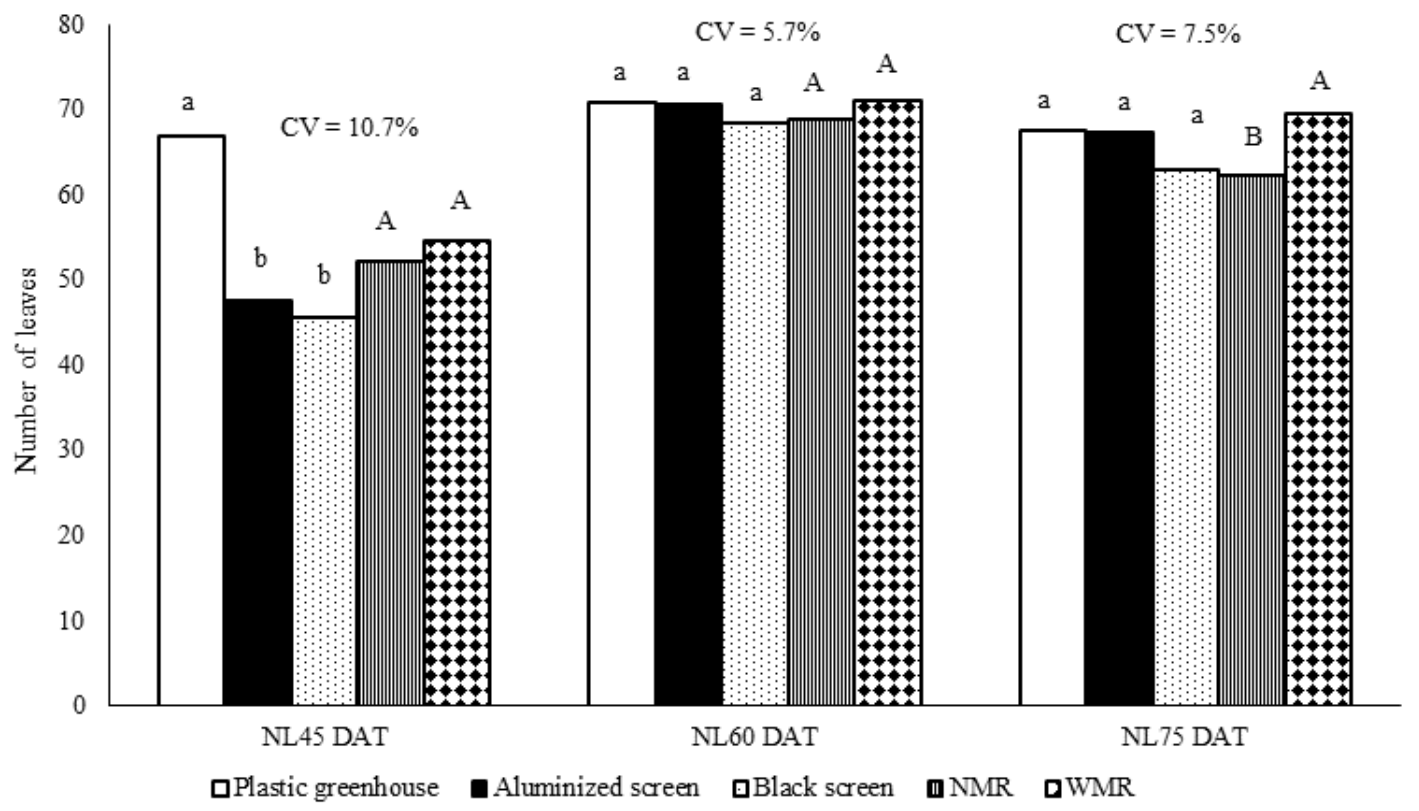

FIGURE 4. Number of leaves (NL) at 45, 60, and 75 days after transplanting (DAT) in protected environments and on growing benches with (WRM) and without (NRM) reflective material. Means followed by the same lowercase letter for protected environments (Tukey test) and uppercase letters for growing benches with and without reflective material (F-test) do not differ from each other at a $5 \%$ probability. $\mathrm{CV}=$ coefficient of variation.

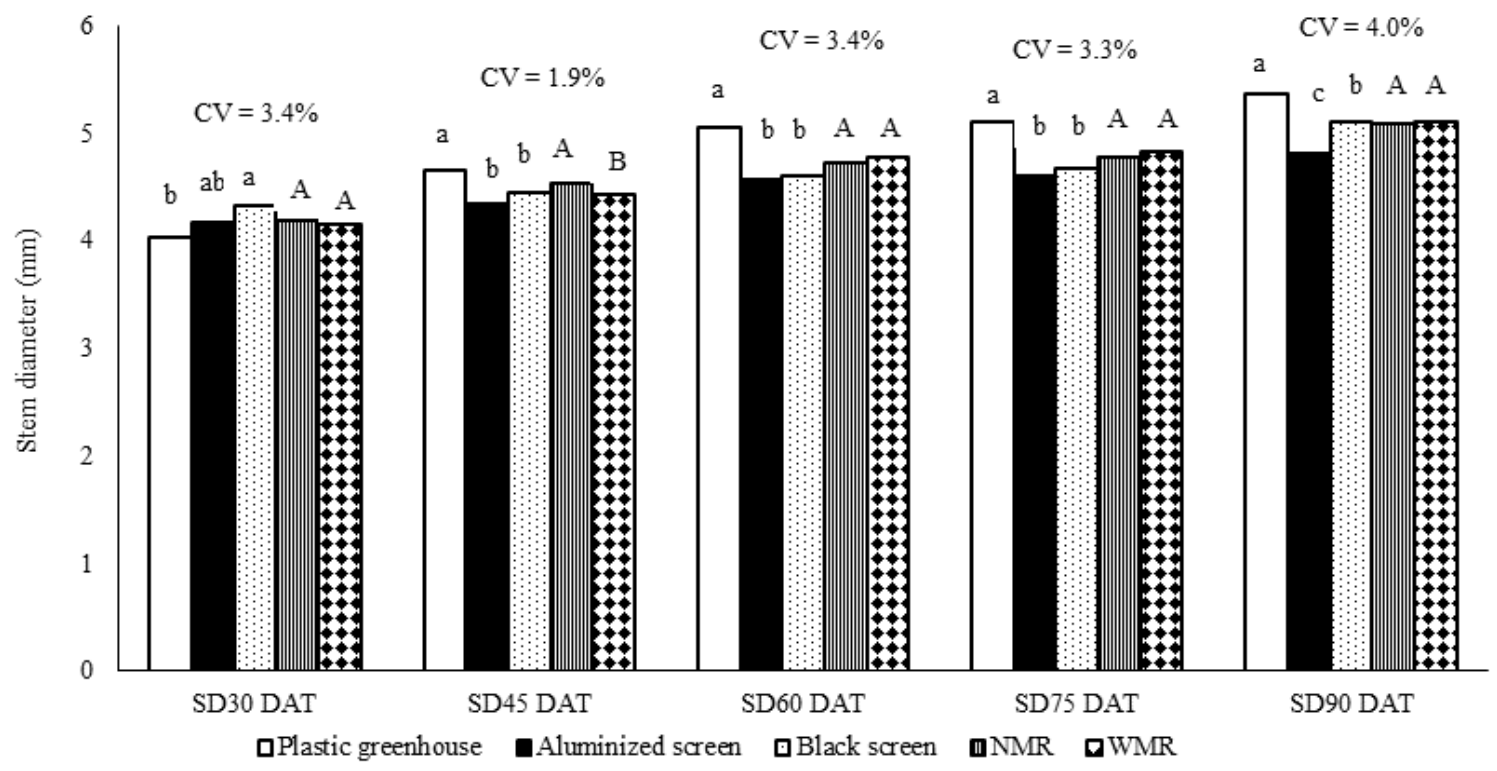

FIGURE 5. Stem diameter (SD) at 30, 45, 60, 75, and 90 days after transplanting (DAT) in protected environments and on growing benches with (WRM) and without (NRM) reflective material. Means followed by the same lowercase letter for protected environments (Tukey test) and uppercase letters for growing benches with and without reflective material (F-test) do not differ from each other at a $5 \%$ probability. $\mathrm{CV}=$ coefficient of variation. 
The reflective material on the growing bench showed no influence on the plant, but this material promoted a better distribution of solar energy for Java plum seedlings, thus increasing the seedling height, as the use of growing benches with reflective material aims to reflect part of the photosynthetically active radiation that reaches the benches to the leaves, which provides higher availability of light energy (Figure 2), improving its use to perform photosynthesis (Salles et al., 2017).

The means between growing benches with and without reflective material were compared in each cultivation environment in isolation for the variables number of leaves (NL30 and NL90) and the number of fruits (NF30, NF45, NF60, NF75, and NF90), for which the ratios between the highest and lowest mean squared residuals resulted in values higher than 7 (Table 5).

TABLE 5. Number of leaves (NL) at 30 and 90 days after transplanting (DAT) and the number of fruits (NF) at 30, 45, 60, 75, and 90 DAT of ornamental pepper plants on growing benches without (NRM) and with (WRM) reflective material in different protected environments.

\begin{tabular}{|c|c|c|c|c|c|c|c|}
\hline & $\begin{array}{c}\text { NL } \\
30 \mathrm{DAT}\end{array}$ & $\begin{array}{c}\text { NL } \\
90 \mathrm{DAT}\end{array}$ & $\begin{array}{c}\text { NF } \\
30 \mathrm{DAT}\end{array}$ & $\begin{array}{c}\mathrm{NF} \\
45 \mathrm{DAT}\end{array}$ & $\begin{array}{c}\text { NF } \\
\text { 60DAT }\end{array}$ & $\begin{array}{c}\text { NF } \\
75 \text { DAT }\end{array}$ & $\begin{array}{c}\text { NF } \\
90 \mathrm{DAT}\end{array}$ \\
\hline & \multicolumn{7}{|c|}{$35 \%$ shading aluminized screen } \\
\hline NRM & $36.59 \mathrm{a}$ & $62.00 \mathrm{a}$ & $0.37 \mathrm{a}$ & $4.21 \mathrm{a}$ & $5.29 \mathrm{a}$ & $9.70 \mathrm{a}$ & $9.79 \mathrm{~b}$ \\
\hline WRM & $33.41 \mathrm{a}$ & $71.46 \mathrm{a}$ & $0.29 \mathrm{a}$ & $4.12 \mathrm{a}$ & $6.56 \mathrm{a}$ & $11.62 \mathrm{a}$ & $12.33 \mathrm{a}$ \\
\hline \multirow[t]{2}{*}{$\mathrm{CV}(\%)$} & 30.43 & 9.40 & 47.34 & 19.66 & 20.86 & 10.47 & 8.90 \\
\hline & \multicolumn{7}{|c|}{ Agricultural greenhouse with $42 / 50 \%$ shading screen under the film } \\
\hline NRM & $39.50 \mathrm{a}$ & $59.25 \mathrm{a}$ & $0.42 \mathrm{a}$ & $10.33 \mathrm{a}$ & $13.12 \mathrm{a}$ & $12.12 \mathrm{a}$ & $12.91 \mathrm{a}$ \\
\hline WRM & $39.31 \mathrm{a}$ & $71.05 \mathrm{a}$ & $0.41 \mathrm{a}$ & $8.58 \mathrm{a}$ & $15.89 \mathrm{a}$ & $14.39 \mathrm{a}$ & $15.87 \mathrm{a}$ \\
\hline \multirow[t]{2}{*}{$\mathrm{CV}(\%)$} & 10.52 & 11.37 & 106.01 & 16.60 & 22.72 & 16.41 & 16.20 \\
\hline & \multicolumn{7}{|c|}{$30 \%$ shading black screen } \\
\hline NRM & $49.16 \mathrm{a}$ & $61.24 \mathrm{a}$ & $0.54 \mathrm{a}$ & $4.08 \mathrm{a}$ & $5.41 \mathrm{a}$ & $7.45 \mathrm{~b}$ & $7.75 \mathrm{~b}$ \\
\hline WRM & $44.79 \mathrm{a}$ & $62.50 \mathrm{a}$ & $0.29 \mathrm{a}$ & $3.20 \mathrm{~b}$ & $5.58 \mathrm{a}$ & $9.29 \mathrm{a}$ & $9.29 \mathrm{a}$ \\
\hline $\mathrm{CV}(\%)$ & 7.12 & 4.11 & 55.31 & 11.12 & 8.03 & 9.39 & 7.83 \\
\hline
\end{tabular}

Means followed by the same lowercase letter in the column for each variable do not differ from each other by the F-test at a $5 \%$ probability. $\mathrm{CV}=$ coefficient of variation.

The number of fruits and number of leaves inside the agricultural greenhouse did not differ in the growing bench with and without reflective material. The use of the reflective material in the environment of $35 \%$ shading aluminum screen at 90 DAT and $30 \%$ shading black screen at 75 and 90 DAT provided a higher number of fruits, but this material had no interference on the number of leaves (Table 5). The positive influence of the reflective material on the number of fruits is in line with the results found by Santos et al. (2017) for passion fruit seedlings (Passiflora edulis Sims f. flavicarpa Deg.), Salles et al. (2017) for Java plum seedlings (Syzygium cumini), Mortate et al. (2019) for paricá seedlings (Schizolobium amazonicum), Costa et al. (2020b,c) for baru seedlings (Dipteryx alata), and Cabral et al. (2020) for papaya seedlings (Carica papaya). According to Salles et al. (2017), this material reflects part of the photosynthetically active radiation that reaches the benches to the leaves, which provides higher availability of light energy (Figure 2), improving its use to perform photosynthesis.

\section{CONCLUSIONS}

The environment of the agricultural greenhouse covered with low-density polyethylene film and 42/50\% thermo-reflective screen under the film favored the growth of ornamental pepper plants regarding height and diameter and provided early flowering and high fruit production.

The use of the reflective material showed no significant results for plant height, stem diameter, and the number of leaves.
The use of reflective material increased the number of fruits in plants under the environments with $35 \%$ shading aluminized screen and $30 \%$ shading black screen.

\section{ACKNOWLEDGMENTS}

The authors would like to thank the Fundação de Apoio ao Desenvolvimento do Ensino, Ciência e Tecnologia of the State of Mato Grosso do Sul - FUNDECT (FUNDECT/CNPq/PRONEM - MS, Process No. 59/300.116/2015 - No. 080/2015), CNPq, and CAPES.

\section{REFERENCES}

Banzatto DA, Kronka SN (2013) Experimentação agrícola. Jaboticabal, Funep.

Binotti CED, Costa, E, Binotti FFS, Batista TB (2018) Chemical agents and shading levels for the production of pepper seedlings. Engenharia Agrícola 38(4): 450-456. DOI: https://doi.org/10.1590/1809-4430-

eng.agric.v38n4p450-456/2018

Cabral RC, Vendruscolo EP, Martins MB, Zoz T, Costa E, Silva AG. (2020) Material reflectante en bancos de cultivo y paja de arroz sobre el sustrato en la producción de plántulas de papaya. Revista Mexicana de Ciencias Agrícolas 11(8): 1713-1723. DOI:

https://doi.org/10.29312/remexca.v11i8.2481 
Costa E, Alixame D, Silva AG, Pupim RS, Binotti FFS (2020 a) Growth of ornamental pepper in colored containers under protected environments. Engenharia Agrícola 40(5): 581-588. DOI: https://dx.doi.org/10.1590/1809-4430eng.agric.v40n5p581-588/2020

Costa E, Lopes TC, Silva AG, Zoz T, Salles JS, Lima AHF, Binotti FFS, Vieira GHC (2020 b) Reflective material in the formation of Dipteryx alata seedlings. Research, Society and Development 9(8): e430985428, 2020. DOI: http://dx.doi.org/10.33448/rsd-v9i8.5428

Costa GGS, Costa E, Silva EM, Borges RS, Binotti FFS, Vieira GHC, Souza AFGO (2020 c) Shading level, reflective material, and seeding depth on the growth of baru seedlings. Agricultural Engineering International: CIGR Journal, 22 (4), 83-92. Available: https://cigrjournal.org/index.php/Ejounral/article/view/578 5 Accessed: Fev 25, 2021.

Costa E, Mesquita VAG, Leal PM, Fernandes CD, Abot AR (2010) Formação de mudas de mamão em ambientes de cultivo protegido em diferentes substratos. Revista Ceres 57(5): 679-685. DOI: http://dx.doi.org/10.1590/S0034-737X2010000500018

Costa E, Santo TLE, Batista TB, Curi TMRC (2017) Diferentes tipos de ambiente protegido e substratos na produção de pimenteiras. Horticultura Brasileira 35(3): 458466. DOI: http://dx.doi.org/10.1590/s0102-053620170324

Costa E, Prado JCL, Cardoso ED, Binotti FFS (2015) Substrate from vermiculite and cattle manure for ornamental pepper seedling production. Horticultura Brasileira 33(2): 163-167. DOI: https://doi.org/10.1590/S0102-053620150000200005
Ferreira DF (2010) SISVAR - Sistema de análise de variância. Versão 5.3. Lavras, UFLA.

Mortate RK, Costa E, Vieira GHC, Sousa HF, Borges RS, Barbosa WFS, Costa GGS (2019) Levels of shading and reflective material in benches for Schizolobium amazonicum seedlings. Journal of Agricultural Science 11(5): 485-495. DOI: https://doi.org/10.5539/jas.v11n5p485

Oliveira LC, Costa E, Cortelassi JAS, Rodrigues ET (2012) Formation of beetroot seedlings in different protected environments, substrates and containers in Aquidauana region, State of Mato Grosso do Sul, Brazil. Engenharia Agrícola 32(3): 415-422. DOI: https://doi.org/10.1590/S0100-69162012000300001

Rodrigues ET, Leal PAM, Costa E, Paula TS, Gomes VA (2010) Produção de mudas de tomateiro em diferentes substratos e recipientes em ambiente protegido. Horticultura Brasileira 28(4): 483-488. DOI: https://doi.org/10.1590/S0102-05362010000400018

Salles JS, Lima AHF, Costa E (2017) Mudas de jambolão sob níveis de sombreamento, bancadas refletoras e profundidade de semeadura. Revista de Agricultura Neotropical 4(5): 110-118. DOI: https://doi.org/10.32404/rean.v4i5.2181

Santos TV, Lopes TC, Silva AG, Paula RCM, Costa E, Binotti FFS (2017) Produção de mudas de maracujá amarelo com diferentes materiais refletores sobre bancada. Revista de Agricultura Neotropical 4(4): 26-32. DOI: https://doi.org/10.32404/rean.v4i4.178

Taiz L, Zeiger E, Møller IM, Murphy A (2017) Fisiologia e desenvolvimento vegetal. Porto Alegre, Artmed, 6 ed. 